\title{
LARGACTIL IN ANAESTHESIA
}

\author{
S. L. VANDEWATTIR, M.D., F.R.C.P(C), and \\ R. A. GorDON, B.SC., M.D., F.R.C.P. (C),F.F.A.R.C.s. ${ }^{* *}$
}

\section{CHEMISTRY}

Largactl (Chlorpromazine) is a compound synthesized by the Rhone-Poulenc laboratories of France (RP. 4560) in 1950, and introduced for clinical use by Laborit in 1951 (1). It is one of a series of synthetic compounds derived from phenothiazine. The substance is a white odourless powder, freely soluble in water, chloroform, and alcohol, but insoluble in ether. A 5 per cent solution in water has a $\mathrm{pH}$ of 4.0 to 6.5 , and is incompatible with thiopentone, gallamine triethiodide (Flaxedil) and decamethonium bromide (Syncurine). (It is compatible with d-tubocurarine chloride and succinyl-choline.) The chemical formula is

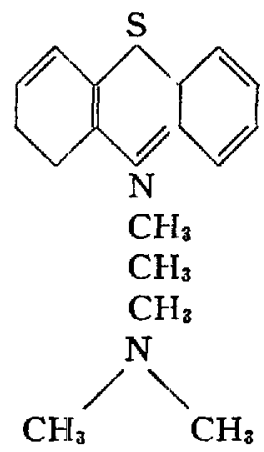

\section{Pharmacology}

Although much has been written on the action and the use of Largactil, particularly in the French literature, it is still not clear just where and how the drug acts. The pharmacological knowledge of the drug is still highly theoretical, based on observations of clinical effects. The action appears to be mainly one of depression, particularly of the central autonomic nervous system.

The autonomic nervous system is concerned with those processes which normally are beyond voluntary control and are, for the most part, beneath conciousness. Through its various activities, the autonomic system exercises the important function of maintaining the constancy of the fluid environment of the body's cells. It sérves to combat forces, acting either from without or fron within, which tend to cause variations in this environment. Regulation of the composition of the body fluids, of their temperature, quantity, and distribution, and perhaps also their metabolism, is effected through the actions of the autonomic nerves upon circulatory, respiratory, excretory, and glandular organs. The stability of

'Presented at the Annual Meeting, Canadian Anaesthetısts' Society, Vancouver, British Columbia, June 14-15, 1954.

* From the Department of Anaesthesia, University of Toronto, and the Toronto General Hospital. 
the internal environment which is characteristic of the healthy body is spoken of by Cannon as homeostasis. According to Cannon (2), the essentral and particular function of the autonomic system is to bring about the internal adjustment upon which this constant state depends.

Labornt postulates that the autonomic system overadjusts or overshoots the mark in attempting to restore homeostasis, in the reaction to stress, and that equilibrium is only restored after hours or days. This "counter shock" phase of Laborit stımulates the endocrne defence mechanism (the stress reaction of Reilly and of Selye), i.e. the autonomic-hypothalamus-pituitary-adrenal cortex system, resulting in such things as hyperthermia, negative nitrogen balance, tachycardra, weight loss, sweating. Laborit and Huguenard (3) investigated various phenothiazine derivatives, in an attempt to stabilize the autonomic nervous system, and to lessen the hormonal reaction. From this evolved Largactil.

Largactıl is sard to be ganghoplegic, vagolytıc, sympatholytic; and slightly anti-histaminic.

\section{Central Effects}

Largactil has a blocking action on the activity of the autonomic ganglia of the hyppothalamus. It is through this blockade that the autonomic stımuli of stress are thought to be prevented from reaching the pitutary gland It is also possible that this hypothalamic blockade dampens the appreciation of pain, as the pain tracts pass through this area on the way to the cerebral cortex The body's awareness of its environment is through proprioceptive reflexes, which also pass through the hypothalamus, and the dampening of these reflexes might account for the state of indifference to the environment that is noted in concious patients given Largactl, rather than a direct cortical depression. There is a reduced response to central nervous system stimulants such as coramine, nikethamide, caffeme, and amphetamme. There is a loss of temperature control, and it is reported that an actual hypothermia occurs, perhaps by depression of the temperature-regulating centre, or because of the peripheral vasodilatation with its increased heat-dissipatıng effect. Largactıl has been reported as an effective anti-emetic against apomorphine (4) Finally there is a potentiation of the action of hypnotics, analgesics, and general anaesthetics

\section{Peripheral Effects}

Largactil is said to block the autonomic gangha and also to be vagolytic. This blockıng action results in peripheral vasodılatation and postural hypotension, tachycardia, and reduction of the autonomic vasopressor reflexes and loss of sweating. Largactil reduces or reverses the hypertensive effect of adrenalin, comparable to dibenamine, but the effect of noradrenalin is not changed.

\section{Use of LaRgactil in Anaesthesia}

From the above discussion, Largactil could have a definite place in clinical anaesthesia as a sedative, in potentiation of general anaesthetics, as an aid in the technique of induced hypothermia, and to reduce postoperative emesis. Preoperative sedation with $25-50 \mathrm{mgm}$. of Largactil without hypnotics or analgesics 
produces a tranquil, quiet, co-operative patient, asleep but not depressed. The induction of general anaesthesia is smooth, rapid, with no excitement and little or no coughing on intubation. Similarily Largactil may be useful in the postoperative period for sedative substitution, in reducing pain and discomfort, with little depression, unless combined with the usual dosage of analgesics or narcotics.

It is generally agreed that Largactil does potentiate general anaesthetics, both intravenous and inhalation. This poteniation occures even when Largactil is used as a preoperative sedative, and particularly so when given during anaesthesia. This effect is of some importance in the elderly and poor-risk patients, who can be maintained in a light plane of anaesthesia, with less of the desressant agents. In some instances, repeated preoperative and operative use o: Largactil has produced a state of anaesthesia, where surgery can be carried out without other agents.

Finally Largactil may be a useful adjunct in the technique of induced hypothermia for intracardiac and intracranial surgery. It in itself may lower the temperature somewhat, and reduce the cooling time and the amount of analgesia or anaesthesia necessary to prevent shivering.

\section{Cutnical Study}

Since Hudon of Quebec introduced Largactil into this country (5), much discussion and interest have been aroused over it. Our curiosity was aroused as to whether Largactil does in fact decrease the stress reaction to surgical trauma, potentiate anaesthetics, reduce blood loss during surgery, and reduce the amount of postoperative narcotics. We were curious to determine whether there was really any advantage in its use, or whether the promoters were a little overexuberant.

We have used Largactil in a small series of 144 cases of major surgery, mainly gastro-intestinal resections, pelvic and thoracic and neck dissections. The age of these patients varied from 17 years to 80 years. The average age was 37.5 years. The drug was used in the following five ways:

1. Premedication: 25-50 mgm. intramuscularly or intravenously (slow drip), with and without other sedatives.

2. 25-50 mgm., single dose or repeated after 3 hours, during anaesthesia, associated with all commonly used anaesthetic agents.

3. Administered during anaesthesia and for a variable time every $4-6$ hours in the postoperative period up to 48 hours.

4. Administered in the postoperative period alone.

5. As above, with and without Phenergan, 108 cases with Largactil alone, 36 cases with equal dosage of Largactil and Phenergan.

\section{ObSERVATTONS}

Our observations on the effects of Largactil have been varied, but on the whole agree with those of other observers. It must be admitted that it is easy to become over-enthusiastic, and that clinical observations are very apt to be exaggerated in favour of the drug. 


\section{Sedative Effect}

Largactil, with or without Phenergan, does produce a tranquil state, or a state of indifference. Some patients, particularly women, who are known to be nervous and excitable, come to the operating room quiet, usually with their eyes closed, but will respond to questioning and are co-oper ative. They take no notice of the surroundings and don't object to vena-puncture. They are depressed but not in the same sense as with morphine-there is no comparable respiratory depression particularly in the elderly.

\section{Potentiation of Sedatives, Anaesthetics, and Relaxants}

The preoperative and postoperative effects of analgesics for sedation are definitely enhanced, and their side reactions of respiratory and cerebral depression increased, in some cases alarmingly. If morphine or Demerol have to be given, $1 / 2$ to $1 / 3$ of the dose would suffice. Codem and aspirin would probably be sufficient in most cases.

All inhalation and intravenous anaesthetic agents were potentiated by Largactil. It was difficult at first to judge the proper amount of cyclopropane and diethyl ether which would maintain light anaesthesia without producing profound and prolonged postoperative depression. When Largactil was given as a sedative, the sleep dose of thiopentone required was much less than expected. After the drug was used in combination with all agents, the best combination was thought to be undoubtedly nitrous oxide and intravenous Demerol or nitrous oxide with Trilene. From the standpoint of postoperative depression, it was amazing in many cases to find how little general anaesthesia was required.

There appeared to be a potentiation of all relaxants. This was true of d-tubocurarine, gallamine triethiodide, decamethonium bromide, laudolissin, and succinylcholine. Good abdominal relaxation could be obtained and maintained for longer periods than expected with a dose of relaxant considered to be smaller than usual.

The various anaesthetic agents and combinations with which Largactil has been used in this series are shown in Table I.

TABLE I

Anaesthetic Combinations With Largactil

\begin{tabular}{lc}
\hline Demerol $/ \mathrm{N}_{2} \mathrm{O} / \mathrm{O}_{2}$ & 34 \\
Pentothal $/ \mathrm{N}_{2} \mathrm{O}$ & 21 \\
Cyclopropane & 48 \\
Ether & 22 \\
$\mathrm{~N}_{2} \mathrm{O} /$ Trulene & 19 \\
\hline Total cases & 144 \\
\hline
\end{tabular}

\section{Cardiovascular Effects}

Two effects commonly noted were tachycardia and hypotension. These occurred no matter how slowly or quickly or by what route the Largactil was given, or with what other agents it was used. However the occurrence of hypotension was more common and more profound when Largactil was given (quickly) 
intravenously, and when the patient was so positioned as to favour pooling in the lower extremities. At the personal suggestion of Laborit, we then combined Phenergan with Largactil in equal amounts and found hypotension to occur less frequently.

Hypotension occurred in all but fourteen of the cases, and the drops in systolic pressure varled from 10 to over $70 \mathrm{~mm}$. $\mathrm{Hg}$ In cases where the fall was greater than $30 \mathrm{~mm}$. during operation, it was usually associated with an operative position conducive to pooling of the blood.

In two cases where $50 \mathrm{mgm}$. of Largactl were given in slow intravenous drip as a preoperative sedative, combined with $1 / 6 \mathrm{gr}$. morphine and $50 \mathrm{mgm}$. Demerol respectively, the blood pressure fell from $205 / 90$ to $130 / 80$, and $165 / 80$ to $128 / 65$ in one hour prior to induction of anaesthesia. This profound fall in pressure was not noted when these analgesics were omitted. In those cases where the fall in pressure was over $30 \mathrm{~mm}$. $\mathrm{Hg}$., and where the patient was in a pooling type of position, the hypotension remained throughout the duration of the operation and on into the postoperative period. This prolonged hypotension was not viewed with alarm except in the elderly and poor-risk patient. Hypotension associated with Largactil is difficult to reverse, in contrast to that caused by the hexamethonium salts and Arfonad. Pressor drugs, such as Methedrine, had little or no effect or only a mild temporary effect. To 1 aise the pressure one had to resort to the use of blood transfusion, plasma expanders, or noradrenalin. In most cases, however, the hypotension was allowed to contınue, and the pressure gradually returned to normal in from 15 minutes to 5 hours. However this prolonged hypotension into the postoperative period, especially if associated with anoxia, confused the picture and it could possibly mask postoperative haemorrhage.

In most cases, it was estımated that blood loss was reduced, and in many cases the loss was nll. No accurate measurement of blood loss was made, but the reduction in blood loss was thought to be largely due to the hypotension. In five cases hypotension was deliberately induced with hexamethonium or Procaine amide, little of either being necessary.

The hypotension experienced in this series is tabulated in Table II.

TABLE II

\begin{tabular}{|c|c|c|c|c|c|}
\hline \multirow{2}{*}{$\begin{array}{c}\mathrm{Mm} . \\
\mathrm{Hg} \\
\text { fall }\end{array}$} & \multicolumn{2}{|c|}{ Normotensive- up to $140 \mathrm{~mm} \mathrm{Hg}$} & \multirow{2}{*}{$\begin{array}{c}\mathrm{Mm} \\
\mathrm{Hg} \\
\text { fall }\end{array}$} & \multicolumn{2}{|c|}{ Hypertensive-over $140 \mathrm{~mm} \mathrm{Hg}$} \\
\hline & Operative & Postoperative & & Operative & Postoperative \\
\hline 0 & 37 & 14 & 0 & 1 & 0 \\
\hline $0-10$ & 15 & 8 & $0-10$ & 0 & 0 \\
\hline $10-20$ & 12 & 8 & $10-20$ & 2 & 1 \\
\hline $20-30$ & 14 & 15 & $20-30$ & 2 & 0 \\
\hline $30-40$ & 19 & 24 & $30-40$ & 3 & 0 \\
\hline $40-50$ & 12 & 23 & $40-50$ & 3 & 0 \\
\hline \multirow[t]{2}{*}{$50 \times$} & 16 & 18 & $50 \times$ & 6 & 10 \\
\hline & 125 & & & 17 & 1 \\
\hline Total & 142 & & & & \\
\hline
\end{tabular}




\section{Postoperative Period}

Postoperative depression and delay in regainung consciousness was a common observation. As noted previously this was particularly so when either cyclopropane or ether had been the principal anaesthetic agent, even in minimal amounts. The least depression, and the smoothest postoperative course was when Largactil (with or without Phenergan) had been combined with a small dose of Thiopentone (usually less than $250 \mathrm{mgm}$.), Demerol (usually under $100 \mathrm{mgm}$.) and nitrous oxide.

On regaining conciousness, the patients appeared more comfortable and in less pain and more cołoperative than those who had not received Largactil. This was particularily noticeable in the recovery room with two patients who had had the same operation, one with Largactil, the other without. At the end of the first 24 hours, patients who had received Largactil (even only one dose) appeared more comfortable, their skin was warm, dry, and pink, they were more cheerful and relaxed and in many cases hungry.

The need for postoperative sedation was thought to be reduced, although this observation has not been controlled. The average time for the need of the first sedative was 6-8 hours, varying from 1 to 24 hours and ten cases (all major surgery) required none. This was difficult to assess, for in many cases we felt that sedatives were given unnecessarnly. Sedatives if necessary had to be given cautiously with reduced dosage, even 10-12 hours after the Largactil had been given, otherwise depression of cough and respiration would occur.

Postoperative emesis was conspicuous by its near absence, occurring in 8.3 per cent of cases, a percentage which is significantly lower than that found in unselected non-Largactil patients reported elsewhere (4] per cent) (6).

Postoperative urinary retentıon occurred frequently, over 12 hours in 54 per cent of the cases, and 20 per cent of the total had to be catheterized in the first 24 hours.

\section{Laboratory Studies}

In an attempt to investigate the effect of Largactil on the stress reaction, some laboratory studies were made. It is generally agreed that a fall in the total eosinophile count below 50 per cu. $\mathrm{mm}$. is a measure of an adequate adrenal response to stress. This response can also be demonstrated by measuring the 24-hour urine steroid output.

According to Laborit (3), Largactil diminishes the autonomic stimulation of the pituitary gland, and thus either blocks or decreases the pituitary-adrenal response; in other words it blocks the stress reaction. If this be so, the postoperative eosinophile counts and urine steroid levels should remain relatively normal, indicating little or no adrenal stimulation.

Our observations, although made only with a few cases, and certainly not conclusive, do not bear out this hypothesis. In the cases studied, Largactil did not significantly alter the stress reaction as far as it was nneasured by preoperative and postoperative eosinophile counts and urine steroid levels.

The results of these investigations are shown in Table III. 
TABLE III

\begin{tabular}{|c|c|c|c|c|c|c|c|}
\hline \multirow{2}{*}{ Case } & \multirow{2}{*}{ Largactil } & \multicolumn{2}{|c|}{$\begin{array}{l}\text { Total Eosinophile } \\
\text { per cu. mm. }\end{array}$} & \multicolumn{2}{|c|}{$\begin{array}{l}\text { Urine } \\
17 \text { Ketosteroids } \\
\text { per } 24 \mathrm{hr}\end{array}$} & \multicolumn{2}{|c|}{$\begin{array}{c}\text { Urine } \\
\text { Corticoids } \\
\text { per } 24 \mathrm{hr} .\end{array}$} \\
\hline & & $\begin{array}{l}\text { preop. } \\
\text { day }\end{array}$ & $\begin{array}{l}\text { postop. } \\
\text { day }\end{array}$ & preop. & postop. & preop. & postop. \\
\hline Lobectomy & None-control & 311 & 22 & 4.8 & 8.7 & 1.7 & 3.5 \\
\hline Decortication & $50 \mathrm{mgm}$. & 288 & 22 & 1.4 & 3.6 & $1: 3$ & 5.0 \\
\hline Lobectomy & 175 & 100 & 0 & - & - & - & - \\
\hline Lobectomy & 100 & 231 & 5 & 2.5 & 2.9 & 2.2 & 6.4 \\
\hline $\begin{array}{c}\text { Thoracotomy } \\
\text { inoperable }\end{array}$ & 100 & 144 & 77 & - & - & - & - \\
\hline $\begin{array}{l}\text { Total } \\
\text { gastrectomy } \\
\text { spleenectomy }\end{array}$ & 100 & 88 & 55 & - & - & - & - \\
\hline $\begin{array}{l}\text { Vaginal } \\
\text { hysterectomy }\end{array}$ & 50 & $154^{\circ}$ & 22 & 1.6 & 4.2 & 0.8 & 1.9 \\
\hline $\begin{array}{l}\text { Excis vulva } \\
\text { \& bilateral } \\
\text { inguinal block } \\
\text { dissection }\end{array}$ & 50 & 55 & 0 & 3.3 & 4.4 & 1.0 & 3.6 \\
\hline
\end{tabular}

\section{Discussion}

From our experience with Largactil in anaesthesia we feel that the drug has a definite place in our armentarium and particularly for poor-risk patients and in major surgical procedures. We feel that in this respect its value lies principally in the reduction of the quantities of more depressing and toxic agents required for satisfactory surgical anaesthesia, and in the reduction of the postoperative reaction of the patient to pain and trauma. We feel that this drug should not be used simply as an adjunct to usual anaesthetic techniques, but rather consider its use to require new and almost homeopathic concepts in the administration of other agents.

Our studies have not borne out the theory that this drug abolishes the normal pituitary-adrenal reactions in response to stress, although our observations of the general effects of the drug on the surgical patient correspond with those reported by others.

We think it worthy of note that in spite of the frequent occurrence of prolonged postoperative depression in our series there has been no notable increase in the postoperative complications which one might expect this to produce. There have been two cases of postoperative pulmonary atalectasis, one coronary thrombosis, and one unexplained late hypotension occurring 12 hours post-operatively. Four patients died in hospital of surgical complications unrelated to anaesthesia.

Postoperative vomiting is reported in 8.3 per cent of these cases, but no patient had serious vomiting, and with one exception these patients vomited only once, and usually 4-8 hours postoperatively. 


\section{Other Uses}

We are studying the use of Largactil in the control of hyperemesis gravidarum, in the anaesthetic management of the normal obstetrical patient, in the control of intractable pain, and in the management of generalized hypothermia for cardiac and neurologićal surgery. These matters will be the subjects of further reports

\section{SUMMARY}

This report has dealt with observations made on the use of Largactil in 144 patients undergoing major surgịcal operations. Its action as a preoperative sedative drug and in the potentiation of action of anaesthetic agents and relaxants during operation has been described. The effect on the postoperative period has been discussed, and data relevant to the complications encountered in its use have been given. Some laboratory investigations relating to its effect on the physiological responses to stress are tabulated.

\section{RÉSUMÉ}

Les auteurs ont rapporté des observations faites au sujet du Largactil en anesthésie dans $1 Q 4$ cas de patients subissant des procédés chirurgicaux majeurs. On a découvert que la drogue augmentait l'action des anesthétnques et des sédatifs. Lorsqu'elle est administrée seule, elle a causé de la tachycardie et de l'hypotension chez la plupart des patients. Ces effets ont été réduits lorsque la drogue a été employée en association avec le Phenergan en quantités égales. Dans le plus grand nombre de cas, ,on a estimé c ue la perte de sang étart réduite, cette réduction de saignée étant attribuable à l'-yypotension.

Durant la période post-opératoire un révell retardé devient une observation commune, en particulier lorsque le cyclopropane ou l'éther constitue l'agent anesthésique principal. Une dépression moindre et une evolution post-opératoire plus égal ont été observés lorsque le Largactil (avec ou sans Phenergan) a été combiné à une petite dose de Thiopentone, de Démerol ou de Protoxyde d'Azote. La nécessité du sédatif après l'opération a été réduite et les sédatifs lorsqu'on a dû y avoir recours ont été nécessairement administrés soigneusement et en doses considérablement réduites afin d'éviter la dépression respiratoire et la toux réflexe. Les vomissements après l'opération ont été rares. La rétention d'urıne après l'opération a été fréquemment observée.

La mesure avant et après l'opération d'excrétion urinaire stéronde et la réponse éosinophile dans un petit nombre de patients n'ont pas démontré une altération appréciable dẹ réponses pituitaires-ádrénaline au « stress ».

\section{ACKNOWLEDGMENT}

We wish to acknowledge the kindness of Poulenc, Ltd. in supplying the drugs used in this study, 


\section{REFERENCES}

1. Laborit, H. \& Huguenard, P. L'hibernation artificielle par moyens pharmacodynamiques et physiques. Presse méd., 13 octobre, 1951.

2. Cannon, W. B. The Autonomic Nervous System: An Interpretation. Lancet 1:1109 (1930).

3. Laborit, H, Huguenard, $P$, \& Allaume, R. Un nouveau stabilisateur neuro-végétatif, le 4560 R.P. Presse méd, 13 février, 1952.

4. Boyd, E. M., Boyd, C. E, \& Casseld, W. A. The Antemetic Action of Chlorpromazine Hydrochloride. C.M A.J. 70276 (1954).

5. Hudon, Fernando \& Jacques, André. Artificlal Hibernation Proc. Canad. Anaesth. Soc. (1953).

6 Gordon, R. A., Vandewater, S L, Sleath, G. E., \& Caplin, D. A Study of the Value of Dimenhydrinate and Promethazıne Hyduochlorıde in the Control of Post-Anaesthetic Vomiting Canad. Anaesth. Soc J. 195 (1954). 